\title{
Budget Participation and Internal Control for Better Quality Financial Statements
}

\author{
Agus Bandiyono \\ Politeknik Keuangan Negara STAN \\ E-mail address: \\ agusbandiyono@pknstan.ac.id
}

\begin{abstract}
This study aims to determine the effect of budgetary participation on the quality of the internal control system's financial statements as a moderating variable. This research is a quantitative research with the respondents are the principal, the vice-principal, the teacher, and the school committee of SMA and SMK throughout Tangerang City. SEM PLS was used to analyze this research data. The data used in this study came from a questionnaire collected using the survey method. The results of this study are that budget participation has a positive and significant effect on the quality of financial reports, while the internal control system as a moderating variable has a strong enough influence on the variable of budget participation in improving the quality of financial reports.
\end{abstract}

Keywords: management accounting, budget participation, quality of financial reports, internal control systems, public sector accounting.

\begin{abstract}
Abstrak: Penelitian ini bertujuan untuk mengetahui untuk mengetahui pengaruh partisipasi anggaran terhadap kualitas laporan keuangan sistem pengendalian internal sebagai variabel moderator. Penelitian ini adalah penelitian kuantitatif dengan responden adalah kepala Sekolah, Wakil Kepala Sekolah, Guru dan Komite Sekolah SMA dan SMK Seluruh Kota Tangerang. SEM PLS digunakan untuk menganalisa data penelitian ini. Data yang digunakan dalam penelitian ini berasal dari kuesioner yang dikumpulkan dengan menggunakan metode survei. Hasil penelitian ini adalah partisipasi anggaran berpengaruh positif dan signifikan terhadap kualitas laporan keuangan, sedangkan sistem pengendalian internal sebagai variabel moderator memberikan pengaruh yang cukup kuat terhadap variabel partisipasi anggaran dalam meningkatkan kualitas laporan keuangan.
\end{abstract}

Kata kunci: akuntansi manajemen, partisipasi anggaran, kualitas laporan keuangan, sistem pengendalian internal, akuntansi sektor publik.

\section{INTRODUCTION}

The quality of local government financial reports (LKPD) continues to increase. Based on the results of the examination by the Supreme Audit Agency (BPK), the Unqualified Opinion (WTP) achieved by LKPD increased from 58 percent (313 LKPD) in 2015 to 82 percent (443 LKPD) in 2018. According to the Chairman of BPK Djanegara (2018), The increase in the quality of LKPD This is partly because the Regional Government (Pemda) has made improvements to weaknesses that occurred in previous years. Minister 
of Finance, (Sri Mulyani Indrawati, 2018) urged all ministries/institutions as well as local governments not to be satisfied with the title of Unqualified (WTP) from the audit results of their financial reports by the Supreme Audit Agency (BPK). In fact, despite receiving WTP status, there are still many regional heads involved in corruption cases.

Quality financial reports are reports that have accountability and transparency. Accountability and transparency of financial reports are often a problem for the regions. Regional Government Financial Reports (LKPD) have not been able to provide satisfaction or confidence in the community. Local governments are expected to prepare themselves with regulations concerning financial governance based on government accounting standards, this is because the indicator of financial accountability can be seen from good financial reports.

The government in 2020 allocates a fund of Rp. 505.8 trillion from APBN 2020. This budget is equivalent to $20 \%$ of the total APBN and from this budget the government allocates Rp. 54.31 trillion for School Operational Assistance (BOS) funds. The distribution of BOS funds has so far been an arena for corruption for local government officials and school principals. Minister of Finance, (Sri Mulyani Indrawati, 2018) revealed the mode of corruption of School Operational Assistance (BOS) funds by local government (pemda) and school principals (principals). Besides, local governments also provide regional school operational assistance funds (BOSDA). These two elements of operational assistance are still frequently noted in audits of financial audit agencies.

Based on data released by the Indonesia Corruption Watch (ICW), from 2005 to 2016 there were 93 cases of corruption in schools with state losses of Rp. 136 billion and involving 65 school principals and 27 school treasurers. This corruption occurs due to weak supervision carried out by the community and internal institutions itself. The results of the investigation by the Financial and Development Supervisory Agency (BPKP) that weak internal control is one of the causes of corruption in government. The Government's Internal Control System can prevent corruption, compared to repressive actions (Bahdin, 2014).

The concept of the Millennium Development Goals (MDGs) which is one of the government's programs still needs improvement. The Millennium Development Goals (MDGs) Program and its derivatives have not been implemented by the government in a transparent and participatory manner. As a result of the Millennium Development Goals (MDGs) program which was not transparent and participatory, the budget channeled or budgeted by the government was not on target. Based on the FITRA study, the government program budget in the name of the MDGs in each ministry continues to increase from year to year. The average budget growth for programs to improve maternity and child health increased by 14 percent during 2006-2013. Even in 2010-2011, it achieved a growth of 38.6 percent.

According to FITRA, one of the factors that caused the MDGs program budget to not be optimal was the absence of public control. As a result, many programs are not welltargeted and most of the budget-related to maternal and child mortality at the Ministry of Health, the majority, almost 75 percent, is spent on official travel expenditures. The details of the activities listed were dominated by the agenda for coordination meetings, outreach, facilitation, and monitoring and evaluation. Transparency and public participation will enable citizens to influence the development and implementation of development goals and priorities. Public participation can also monitor what the government is doing with public resources to achieve the MDGs. Besides, public participation must also ensure that the 
government is accountable for the actions and policies they decide to make (Hardia Utama, M, 2015).

Budgeting in an institution is usually done by asking for input from employees or involving employees (bottom-up) but there is also an institution that prepares a top-down budget, meaning that employees only know the budget prepared by management (Bandiyono and Saputro, 2020); (Bandiyono, 2019). Each of these budget preparation methods has its own advantages, namely the bottom-up method is usually more aspirational and in its implementation, the employees also supervise, while the top down method tends to be faster, but the employees in its implementation just carry it out without feeling the need to participate. Supervise in its implementation. (Bandiyono and Al Fikri, 2020)

Internal control is very important in maintaining the implementation of the budget plan. Budget objectives will be achieved if there are tight and reliable controls. According to (Hoesada, 2013), there are three types of government management control, namely preventive control, operational control, and performance control. It is hoped that adequate internal supervision will improve the quality of financial reports. Participating employees in budgeting and sharing the need to oversee the implementation of a budget plan will reduce the potential for fraud.

(Aditya and Surjono's, 2017) states that the internal control system has an influence on the quality of regional financial reports by $36.36 \%$ while the remaining $63.64 \%$, the quality of regional financial reports are influenced by other factors. Hypothesis testing results in count 2.831>t table 2.145, then Ho is rejected and Ha is accepted, meaning that there is an influence between the internal control system on the quality of regional financial reports at the Regional Revenue Service Branch Office of Sukabumi II Pelabuhan Ratu Regency.

(Herawati's, 2014) concluded that there was a significant influence between Control Environment, Risk Assessment, Control Activities, Information and Communication, and Monitoring on the Quality of Financial Statements simultaneously; partially, there is a significant influence between the Control Environment, Risk Assessment, and Information and Communication on the Quality of Financial Statements; Partially, there is an insignificant influence between Control and Monitoring Activities.

According to research by (Uleng, 2019) Budget participation does not affect the quality of information on local government financial reports. The results of this study do not correspond to agency theory and are not in line with previous research results. Internal control is not able to significantly moderate the relationship between budget participation and the quality of information on local government financial reports. These results are not in line with the decision-usefulness theory but are supportive.

\section{THEORETICAL REVIEW}

Budget Participation. Based on (Hansen and Maryanne, 2009) participatory budgeting is a participatory budget that allows lower-level managers to participate in budgeting rather than burdening the budget to lower-level managers. (Dharmanegara, 2010); (Apriantini et al., 2014) defines budget participation as a joint decision-making process by two or more parties where the decision will have a future impact on those who make it, in other words, lower-level workers and managers have a say in the process. Budget participation is a budget prepared with the full cooperation and participation of all managers at all levels. 
According to (Sumarno, 2005) the characteristics of participation in budgeting can be seen from various factors, namely: a) a large influence on participation in budget measurement; b) influence in the budget preparation revision; c) the influence of opinions/proposals in budgeting; d) confidence in deciding a budget; 5) the importance of the contribution of suggestions or thoughts in budget preparation; f) participation in budget preparation activities.

According to (Supriyono, 2000) the basic principles in budgeting are; a) management involvement, b) organizational adaption, c) accounting responsibility, d) full communication, e) timeliness, f) reward and punishment.

Financial Report Quality. (Kieso et al., 2012) suggests that the quality of financial reporting refers to the quality of accounting information, namely the qualitative characteristics of accounting information. (Agoes, 2012) states that the examination of financial statements will produce quality financial statements that produce an opinion from the examiner's professional statement regarding the fairness of the information from the financial statements. (Heizer and Render, 2006) "Quality is the totality of features and characteristic of a product or service that bears on its ability to satisfy stated or implied need."

(Siregar, 2015), the qualitative characteristics of financial statements are normative measures that need to be embodied in accounting information so that they can fulfill their objectives. There are four qualitative characteristics of financial reports, namely:

Relevant. Information that has retrieval benefits, predictive benefits, is presented on time, and is complete.

Reliable. The information presented is honest, verifiable, and neutral.

Can be compared to. The financial statements can be compared between periods and among governmental units.

Understandable. Information stated in a form and terms that can be understood by the user.

(Belkaoui, 2004) describes the scope of financial reporting in Statement of Financial Accounting Concepts No. 1, Objective of Financial Reporting by Business Enterprises are as follows: "Financial reporting includes not only financial statements but also other means of communicating information that relates, directly or indirectly, to the information provided by the accounting system - that is, information about an enterprise's resources, obligations, earnings, etc.

Characteristics of quality information are referred to in general purpose financial reporting, which is contained in the conceptual framework for general purpose financial reporting by public sector entities issued by the (International public sector accounting standards board, 2010) (Tambingon, 2018), which is the dimension of the quality of financial reporting are as follows.

Relevance. Financial and non-financial information is relevant if it is capable of making a difference in achieving the objectives of financial reporting. Financial and non-financial information is capable of making a difference when it has confirmatory value, predictive value, or both. It may be capable of making a difference, and thus be relevant, even if some users choose not to take advantage of it or are already aware of it. (Yuliastuti et al., 2015)

Faithful representation. To be useful in financial reporting, information must be a faithful representation of the economic and other phenomena that it purports to represent. Faithful 
representation is attained when the depiction of the phenomenon is complete, neutral, and free from material error. Information that faithfully represents an economic or other phenomenon depicts the substance of the underlying transaction, another event, activity, or circumstance which is not necessarily always the same as its legal form.

Understandability. Understandability is the quality of information that enables users to comprehend its meaning. GPFRs of public sector entities should present information in a manner that responds to the needs and knowledge base of users, and the nature of the information presented. For example, explanations of financial and non-financial information and narrative reporting of achievements and expectations should be written in plain language, and presented in a manner that is readily understandable by users. Understandability is enhanced when information is classified, characterized, and presented clearly and concisely. Comparability can also enhance understandability.

Timeliness. Timeliness means having information available for users before it loses its capacity to be useful for accountability and decision making purposes. Having relevant information available sooner can enhance its usefulness as input to assessments of accountability and its capacity to inform and influence decisions that need to be made. A lack of timeliness can render information less useful.

Comparability. Comparability is the quality of information that enables users to identify similarities in, and differences between, two sets of phenomena. Comparability is not a quality of an individual item of information, but rather a quality of the relationship between two or more items of information.

Verifiability. Verifiability is the quality of information that helps assure users that information in GPFRs faithfully represents the phenomena that it purports to represent.

Internal Control System. (Mulyadi's, 2013) states that: "Internal control is part of a system that includes organizational structure, methods, and measures that are coordinated to maintain organizational wealth, check the accuracy and reliability of accounting data, encourage efficiency and encourage compliance with management policies. (Diana and Lilis, 2011) state that internal control is: "All organizational plans, methods, and measurements chosen by a business activity to secure assets, check the accuracy and reliability of business accounting data, improve operational efficiency, and support compliance. Managerial policies that have been set. " COSO (2013) defines "Internal control is a process, effected by an entity's board of directors, management, and other personnel, designed to provide reasonable assurance regarding the achievement of objectives relating to operations, reporting, and compliance." (Messier, 2010) defines: "Internal control is a design and affected by an entity's board of directors, management, and other personnel, designed to provide reasonable assurance about the achievement of the entity's objectivities in the following category, Reliability of financial reporting, effectiveness, and efficiency of operations, and compliance with applicable laws and regulations. "

A good internal control system according to (Mulyadi, 2013), four main elements must be fulfilled, namely, a) An organizational structure that clearly separates functional responsibilities, b) A system of authority and recording procedures that provides adequate protection for wealth, debt, income and costs, c) healthy practices in carrying out the duties and functions of each organizational unit, d) employees whose quality is following their responsibilities. 
According to COSO (2013) Internal control consists of five integrated components: 1) control environment, 2) risk assessment, 3) control activities, 4) information and communication, 5) monitoring activities ". Internal control dimensions and indicators are (1) general control, consisting of (Hopwood and Unerman, 2010), the organization plans transaction processing, general operating procedures, features equipment control, control over access to equipment and data. (2) control application, comprising: an input control, process control, control output. According to (Arens and Elder, 2006), Internal control includes five categories of control thal management design and implements to provide reasonable assurance that management's control objectives win be met. These are caned components of internal control and are: 1) control environment, 2) risk assessment, 3) information and communication, 4) control activities, 5) monitoring The

Objectives of internal control according to COSO cited by (Sawyer, 2003) are as follows: Internal control is designed to provide adequate assurance regarding achievements in terms of operational effectiveness and efficiency, reliability of financial information, and compliance with applicable laws and regulations. According to (Mulyadi, 2013), the objectives of the internal control system are divided into two types, namely a) Internal Accounting Control (Internal Accounting Control), accounting internal control, which is part of the internal control system, including organizational structure, coordinated methods, and measures. especially to maintain wealth and check the accuracy and reliability of accounting data, b) Internal Administrative Control, administrative internal control, which includes organizational structure, methods, and measures which are coordinated especially to promote efficiency and compliance with management policies.

\section{THEORETICAL REVIEW}

The Effect of Budget Participation on the Quality of Financial Statements. (Hariani and Veny's, 2018) research states that budgetary participation does not affect the performance of local government officials in West Jakarta Administrative City. (Uleng, 2019); (Natalya, Beby et al., 2016) concludes that budget participation does not affect the quality of information on local government financial reports. Research by (Sawitri et al., 2015); (Marfuah and Amanda, 2014) states that budget participation has a positive effect on managerial performance. (Defitri, 2017) states that budgeting participation is very influential and positively significant on the performance of government officials, this proves that the higher participation in budgeting will produce effective information between superiors and subordinates so that communication between superiors and subordinates can run smoothly. Besides, the performance of government officials is also influenced by the clarity of budget targets in a positive and significant way, this proves that with a clear budget target, the budget executing apparatus will also be helped in its realization, this will indirectly affect the performance of the apparatus. One of the reasons for the ineffectiveness and efficiency of the budget is due to unclear budget targets which resulted in local government officials having difficulty in preparing budget targets. (Pebrianti and Aziza's, 2018); (Nouri and Parker, 1996) states that In the planning section of the OPD / regional device organizations in the Bengkulu City Government related to the clarity of the target, it should further increase consistency in the determination of budget targets for strategic and Renja documents, improve quality in determining the achievement of targets every year, for 
financial managers should increase understanding of accountability of each target budget to improve agency performance accountability.

Research by (Lambajang et al., 2018) states that community participation (X2) has a positive and significant effect on regional financial supervision (Y). This shows that the higher the community participation, the higher the resulting regional financial supervision. (Anwar and Sumiati's, 2014) study concluded that budgetary participation affects the performance of local government officials, therefore, the Palopo City DPPKAD must pay more attention than in participating in budgeting it considers its performance more. Research by (Putra et al., 2014) states that there is a significant and positive influence between participation in budgeting on managerial performance in SKPD Buleleng Regency, this is based on the reasons shown as indicated by a significance level of 0.023 PPA with a significance number smaller than 0.05. (Apriantini et al., 2014) in their research stated that there is a positive and significant influence between budgeting participation on budgetary slack and there is a positive and significant interaction effect between a budget emphasis on the relationship between budget participation and budgetary slack.

Based on the above studies, it can be concluded that budget participation has a positive effect on the quality of financial reports.

H1: Budget participation has a positive effect on the quality of financial reports.

The Effect of Budget Participation on the Quality of Financial Statements with the Internal Control System as a Moderating Variable. Based on the research results of (Aditya and Surjono, 2017) it is known that the internal control system on the quality of regional financial reports produces a value of $r=0.603$ shows that there is a strong and positive relationship. Analysis of determination yields $\mathrm{Kd}=36.36 \%$, meaning that the internal control system has an influence on the quality of regional financial reports by $36.36 \%$ while the remaining $63.64 \%$, the quality of regional financial reports are influenced by other factors. Hypothesis testing results in $831.2=$ count $t>145.2=$ table $t$, then Ho is rejected and $\mathrm{Ha}$ is accepted, meaning that there is an influence between the internal control system on the quality of regional financial reports. Based on the results of research by (Mokoginta et al., 2017), it is proven that the International Control System has a significant negative effect on the quality of government financial reports. The results of this study mean that the internal control system at North Bolaang Mongondow BPKAD which has been implemented has been good but in its implementation, it has not been effective and efficient so that it affects the lack of quality of government financial reports. (Budiawan and Purnomo, 2014) states that the internal control system does not have a positive effect on the quality of the financial reports of the Regency / City Regional Government of Bogor, West Java Province. A good internal control system will not necessarily improve the quality of the financial reports of the District / City Government in Bogor I, West Java Province. (Amrullah, 2019) states that the internal control system affects the quality of financial accountability reports.

Based on the above studies, it can be concluded that budget participation has a positive effect on the quality of financial reports with the internal control system as a moderating variable. 
H1: Budget Participation Affects the Quality of Financial Statements with an internal control system as a moderating variable.

Based on several previous studies, the research framework in this study is as follows:

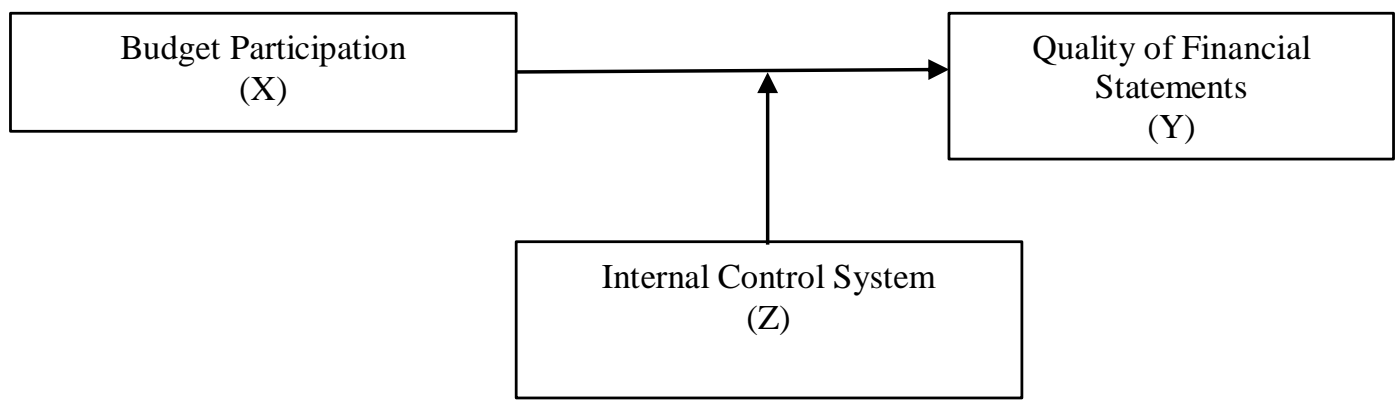

Figure 1. Research Framework

Hypothesis. Based on the literature review and framework, the hypothesis in this study is

\begin{tabular}{|l|l|l|}
\hline $\mathrm{H}_{1}$ & $:$ & Budget participation affects the quality of financial \\
\hline $\begin{array}{l}\text { HSt } \\
\text { atem } \\
\text { ents } 2\end{array}$ & $:$ & $\begin{array}{l}\text { Budget Participation Affects the Quality of Financial Statements } \\
\text { with an internal control system as a moderating variable. }\end{array}$ \\
\hline
\end{tabular}

\section{METHODS}

Sample and Data Collection. In this study, the authors used saturated sampling techniques or census sampling to determine the research sample. In this study, the authors took samples using a purposive sampling technique. The population in this study were all schools under the auspices of the Tangerang City Education Office. The research sample criteria in question are Schools that receive School Operational Assistance Funds for SMA and SMK Kota Tangerang.

Data collection in this study was carried out using a questionnaire technique. Respondents in this study will receive three groups of questionnaires consisting of questionnaire 1 contains budget participation, questionnaire 2 contains internal control systems, questionnaire 3 contains the quality of financial reports.

Measurement of Variable. Measurement of variables in this study using an ordinal scale. The data obtained from the questionnaire is ordinal. Ordinal data is qualitative data that uses numbers as symbols of qualitative data or not actual numbers and statistical procedures, such as regression, t-tests, etc., require that the data be interval scale.

Regression Analysis. Dependent variable with one or more independent variables, to estimate and/or predict the population average or the average value of the dependent variable based on the value of the known variable. The data that has been collected will be analyzed using statistical analysis tools, namely Regression Analysis, the formula is: 


$$
\mathbf{Y}=\alpha+\boldsymbol{\beta}_{1} \mathbf{X}_{1}+\boldsymbol{\beta}_{2} \mathbf{X}_{2}+\mathbf{e}
$$

Information:

Y : Quality of Financial Statements

$\alpha \quad$ : constanta

$\beta 1 \quad$ : regression coefficient

$\beta 2 \quad$ : regression coefficient

$\mathrm{X} 1$ : budget participation

X2 : internal control system

Data Analysis. The data collection method in this study is a survey method. The survey method was used to obtain data on SMA and SMK in Tangerang City that received school operational assistance. Data collection was carried out using a questionnaire. The units of analysis in this study are SMA and SMK located in the Tangerang City area and receive BOS funds. PLS-SEM was used as an analytical tool in this study.

\section{ANALYSIS AND FINDINGS}

Validity Test. The results of the validity test were carried out by calculating the correlation of each research variable. The statement/research variable is declared valid if it has a loading factor above 0.70 of the intended construct. While the loading factor of 0.50 to 0.60 can still be maintained (Ghozali, 2014). The research variable is said to meet the validity if it is positive and the loading factor is above 0.50 . The results of the validity test can be seen in Table.

Table 1. Validity Test

\begin{tabular}{|c|c|c|c|c|}
\hline No & Variable & Dimension & Score & Results \\
\hline \multirow{3}{*}{1} & \multirow{3}{*}{ Participation in the Budget } & $\begin{array}{l}\text { Participation in the } \\
\text { preparation of activity } \\
\text { proposals }\end{array}$ & 0.91 & Valid \\
\hline & & $\begin{array}{l}\text { Involvement in the } \\
\text { discussion of proposals } \\
\text { with the budget team }\end{array}$ & 0.86 & Valid \\
\hline & & $\begin{array}{l}\text { Contribution in } \\
\text { budgeting }\end{array}$ & 0.82 & Valid \\
\hline \multirow{5}{*}{2} & \multirow{5}{*}{$\begin{array}{l}\text { Internal Control System } \\
\text { Control }\end{array}$} & Environment & 0.78 & Valid \\
\hline & & Risk Assessment & 0.77 & Valid \\
\hline & & Control Activities & 0.70 & Valid \\
\hline & & $\begin{array}{l}\text { Information and } \\
\text { Communication } \\
\end{array}$ & 0.80 & Valid \\
\hline & & Monitoring & 0.88 & Valid \\
\hline \multirow{4}{*}{3} & \multirow{4}{*}{$\begin{array}{l}\text { Quality of Financial } \\
\text { Statements }\end{array}$} & Relevant & 0.89 & Valid \\
\hline & & Reliable & 0.91 & Valid \\
\hline & & Easy to understand & 0.92 & Valid \\
\hline & & Can be compared & 0.78 & Valid \\
\hline
\end{tabular}


Reliability Test Reliability test. Results can be measured by two criteria, namely composite reliability and alpha Cronbach. The construct is said to be reliable if the reliability value of the composite and Cronbach alpha is above 0.70. (Gozhali, 2014).

Table 2. Reliability Test

\begin{tabular}{l|c|c|c}
\hline & $\begin{array}{c}\text { Cronbach's } \\
\text { Alpha }\end{array}$ & $\begin{array}{c}\text { Composite } \\
\text { reliability }\end{array}$ & Results \\
\hline Budget Participation & 0.86 & 0.92 & Reliable \\
\hline Internal Control System & 0.92 & 0.96 & Reliable \\
\hline Financial Report Quality & 0.78 & 0.83 & Reliable \\
\hline
\end{tabular}

Based on the table above, it is known that all variables have a value of composite reliability and alpha Cronbach is greater than 0.70 so that all research variables are said to be reliable.

Hypothesis Testing

Effect of Budget Participation on Quality of Financial Statements

Table 3. R-Square Table R

\begin{tabular}{l|r|r}
\hline & \multicolumn{1}{|c|}{ Square } & \multicolumn{1}{c}{ R Square Adjusted } \\
\hline KLK & 0.876 & 0.936 \\
\hline
\end{tabular}

Table 4. Value Path Coefficients

\begin{tabular}{l|r|r|r|r|r}
\hline & $\begin{array}{c}\text { Original Sample } \\
(\mathbf{O})\end{array}$ & $\begin{array}{c}\text { Sample } \\
\text { Mean } \\
\text { (M) }\end{array}$ & $\begin{array}{c}\text { Standard } \\
\text { Deviation } \\
\text { (STDEV) }\end{array}$ & $\begin{array}{c}\text { T Statistics } \\
(\mid \text { O / STDEV |) }\end{array}$ & P Values \\
\hline Budget-> KLK & 0.694 & 0.026 & 0.023 & 14.324 & 0.012 \\
\hline
\end{tabular}

Based on table 3 it can be explained that the R-square value is 0.876 which means the variability construct of the financial report quality $(K L K)$ which can be explained by the budget participation construct, the construct of an internal control system is $87.6 \%$.

Based on table 4 the parameter coefficient is 0.964 , which means that there is a positive influence on budgeting participation in the quality of financial statements. Budgeting participation affects the quality of financial reports by $69.4 \%$ while $30.6 \%$ is influenced by other variables. The higher the participation in budgeting, the better the quality of financial reports. 
The $t$ statistical value is 14,324 while the t table with a significance level of $5 \%$ is 1,960 , so the $t$ statistical value is greater than table $(14,324>1,960)$. This means that budgetary participation has a significant effect.

Based on the facts in the field that participation in budgeting is relatively high because the school budget is compiled together with all school elements, namely the principal, deputy principal, school committee, teachers, and representatives of parents of students.

The results of this study are in line with the research of (Sawitri et al., 2015) which states that budget participation has a positive effect on managerial performance. (Defitri, 2017) states that budgeting participation is very influential and positively significant on the performance of government officials, this proves that the higher participation in budgeting, the more effective information between superiors and subordinates will result so that communication between superiors and subordinates can run smoothly. Relatively the same research results were obtained from the research of (Pebrianti and Nurna, 2018), research by (Lambajang et al., 2018), and (Apriantini et al., 2014).

The results of this study are not following (Hariani and Veny, 2018) research which states that budgetary participation does not affect the performance of local government officials in West Jakarta Administrative City. (Uleng, 2019) concluded that budget participation does not affect the quality of information on local government financial reports.

The Effect of Budget Participation on the Quality of Financial Statements with Internal Control Systems as Moderating variables.

Table 5. Value Path Coefficients

\begin{tabular}{l|c|c|c|c|c}
\hline & $\begin{array}{c}\text { Original } \\
\text { Sample (O) }\end{array}$ & $\begin{array}{c}\text { Sample } \\
\text { Mean (M) }\end{array}$ & $\begin{array}{c}\text { Standard } \\
\text { Deviation } \\
\text { (STDEV) }\end{array}$ & $\begin{array}{c}\text { T Statistics ( | O / } \\
\text { STDEV |) }\end{array}$ & $\begin{array}{c}\text { P } \\
\text { Values }\end{array}$ \\
\hline Budget-> SPI -> KLK & 0.896 & 0.016 & 0.006 & 11.566 & 0.012 \\
\hline
\end{tabular}

Based on table 5 it is known that the parameter coefficient value is 0.896 which means that there is a positive influence on the moderating variable of the internal control system on the quality of financial statements. The internal control system moderating variable affects the quality of financial reports by $89.6 \%$ while $10.4 \%$ is influenced by other variables.

The $t$ statistical value is 11,566 while the t table with a significance level of $5 \%$ is 1,960 , which means that the $t$ statistical value is greater than table $(11,566>1,960)$. This means that the moderating variable of the internal control system has a significant effect on the quality of financial reports.

The results of this study are in line with the research of (Aditya and Surjono, 2017), it is known that the internal control system on the quality of regional financial reports produces a value of $r=0.603$, which indicates that there is a strong and positive relationship. The same results were also obtained from (Amrullah, 2019) which states that the internal control system affects the quality of financial accountability reports.

The results of this study contradict the results of research by (Mokoginta et al., 2017) proving that the internal control system has a significant negative effect on the quality of 
government financial reports. (Budiawan and Purnomo, 2014) states that the internal control system does not have a positive effect on the quality of the financial reports of the Regency / City Regional Government of Bogor, West Java Province. A good internal control system will not necessarily improve the quality of the financial reports of the District / City Government in Bogor I, West Java Province.

\section{CONCLUSION}

Based on the research hypothesis, framework, and discussion, it can be concluded that budget participation has a positive and significant effect on the quality of financial reports. The involvement of school elements in budget preparation gives them the responsibility to participate in supervising the implementation of the budget. The participation of good school elements in preparing a budget will have an impact on the quality of financial reports. Internal control system moderating variables have a positive and significant effect on the quality of financial reports. The internal control system provides improvements in the quality of financial reports. This shows that the internal control system actually functions as a research variable.

Limitation And Future Research. This study aims to contribute to the development of science, but this research has many limitations, namely, the samples in this study only come from high schools (SMA) and vocational high schools (SMK) so that the results of this study cannot be used. to generalize the situation in other areas. The data generated from the questionnaire data do not necessarily indicate the actual situation. The research variable that affects the quality of financial reports is only one variable and one moderating variable, so it is hoped that for the next research, it is expected that for the next research, it will add other variables such as leadership style, compliance with laws and regulations, and competence of human resource axis.

\section{REFERENCES}

Aditya, Oka Reza dan Welly Surjono. (2017). Pengaruh Sistem Pengendalian Intern Terhadap Kualitas laporan Keuangan. Jurnal Sistem Informasi, Keuangan, Auditing dn Perpajakan (SIKAP), Vol. 2 (No. 1) 2017 hal 49-62.

Agoes Sukrisno. (2012). Auditing Petunjuk Praktis Pemeriksaan Akuntan Oleh. Akuntan Publik. Jakarta: Salemba Empat

Amrullah, Ihsan. (2019). Pengaruh Kualitas Sumber Daya Manusia dan Pemanfaatan Teknologi Informasi terhadap Kualitas Laporan Pertanggungjawaban Keuangan dengan Pengendalian Internal Sebagai Variabel Intervening (Studi Empiris BOS SMA/SMK Kota Cilegon). Jurnal Riset Akuntansi Tirtayasa Vol. 04 No. 01.

Apriantini, N. K. E., Adiputra, I. M. P., SE, S., dan Edy Sujana, S. E. (2014). Pengaruh Partisipasi Anggaran Terhadap Senjangan Anggaran Dengan Penekanan Anggaran Dan Komitmen Organisasi Sebagai Variabel Moderating (Studi Kasus Pada Dinasdinas Pemerintah Kabupaten Buleleng). JIMAT (Jurnal Ilmiah Mahasiswa Akuntansi) Undiksha, 2(1)

Anwar, Suhardi M dan Sumiati. (2014). Pengaruh Partisipasi Penyusunan Anggaran Terhadap Kinerja Aparat Pemerintah Daerah (Studi Kasus Pada Dinas Pendapatan, 
Pengelolaan Keuangan Aset Daerah Kota Palopo). Jurnal Manajemen Vol. 01 No. 02 Hal. 84-94.

Arens, A. A., and Elder, R. J. (2006). Perspectives on auditing education after SarbanesOxley. Issues in Accounting Education, 21(4), 345-362.

Bahdin. (2014). https://investor.id/national/lemahnya-pengendalian-internal-penyebab korupsi.

Bandiyono, A. (2019). The Effect of Good Corporate Governance and Political Connection on Value Firm. Jurnal Akuntansi, 23(3), 333. https://doi.org/10.24912/ja.v23i3.599.

Bandiyono, A., and Al Fikri, A. (2020). Four levers of control in the implementation of supply chain management in government institutions. International Journal of Supply Chain Management, 9(2), 1029-1047.

Bandiyono, A., and Saputro, R. D. (2020). Gender mainstreaming in government institutions through effective gender responsive budget. International Journal of Scientific and Technology Research, 9(2), 2009-2023.

Belkaoui, A. (2004). Accounting Theory. Jakarta: Salemba Empat.

Budiawan, Desiana Anugrah dan Budi S Purnomo. (2014). Pengaru.h Sistem Pengendalian Internal dan Kekuatan Koersif Terhadap Kualitas Laporan Keuangan Pemerintah Daerah (Studi Pada Pemerintah Daerah Kabupaten/ Kota di wilayah I Bogor Provinsi Jawa Barat). Jurnal Riset Akuntansi dan Keuangan 2(1) 2014.

COSO. (2013). Internal Control-Integrated Framework: Executive Summary, Durham, North Carolina, May 2013.

Defitri, Siska Yulia. (2017). Pengaruh Partisipasi Penyusunan Anggaran Dan Kejelasan Sasaran Anggaran Terhadap Kinerja Aparat Pemerintah Daerah. Jurnal EKOBISTEK Fakultas Ekonomi, Vol. 6, No. 1, April 2017, Hal 108-118.

Dharmanegara, Ida Bagus Agung. (2010). Penganggaran Perusahaan: Teori dan Aplikasi. Yogyakarta: Graha Ilmu.

Diana, A dan Lilis Setiawati. (2011). Sistem Informasi Akuntansi, Edisi pertama: Andi, Yogyakarta.

Ghozali, Imam. (2014). Structural Equation Modeling Metode Alternatif dengan Partial Least Squares (PLS). Semarang: Badan Penerbit Universitas Diponegoro.

Herawati, Tuti. (2014). Pengaruh Sistem Pengendalian Intern Terhadap Kualitas Laporan Keuangan (Survei pada Organisasi Perangkat Daerah Pemda Cinajur). Jurnal STARStudy and Accounting Research Vol. XI. No. 1.

Hoesada, Jan. (2013). Taksonomi Ilmu Manajemen. Yogyakarta: CV Andi Offset.

Indrawati, Srimulyani. (2018). https://ekonomi.kompas.com/read/2018/ 09/20/ 123447426/sri-mulyani-banyak-laporan-keuangan-daerah-wtp-tapi-kepaladaerahnya-korupsi.

Hariani, Swarmilah dan Veny. (2018). Pengaruh Partisipasi Anggaran, Evaluasi Anggaran, Dan Kesulitan Pencapaian Tujuan Anggaran Terhadap Kinerja Instansi Pemerintah Daerah (Studi Empiris Pada Skpd Walikota Jakarta Barat). Profita: Komunikasi Ilmiah Akuntansi dan Perpajakan, Vol 11 No. 2 Agutus 2018.

Hansen, Don R. dan Maryanne M. Mowen. (2009). Akuntansi Manjerial Buku 2. Edisi 8. Terjemahan oleh Denny Arnos Kwary. Jakarta: Salemba Empat.

Heizer, Jay and Render, Barry. (2006). Operations Management, 8th Edition, Pearson. Prentice-Hall. 
Hopwood, A. G., and Unerman, J. (Eds.). (2010). Accounting for sustainability: Practical insights. Earthscan

International Public Sector Accounting Standard. (2010). A conceptual framework for general purpose financial reporting by public sector entities. The International Federation of Accountants (IFAC); IPSAS. Available from: http://www.fac.rg.

Kieso, D. E., Weygandt, J. J., and Warfield, T. D. (2012). Intermediate Accounting. Jonh Wiley \& Sons.

Lambajang, Amelia A, David PE Saerang, Jenny Morasa. (2018). Pengaruh Pengetahuan Tentang Anggaran, Partisipasi Masyarakat, Transparansi Kebijakan Publik, Dan Akuntabilitas Publik Terhadap Pengawasan Keuangan Daerah Pada Dewan Perwakilan Rakyat Daerah di Wilayah Sulawesi Utara.

Marfuah dan Amanda Listiani. (2014). Pengaruh Partisipasi Anggaran Terhadap Senjangan Anggaran Dengan Menggunakan Komitmen Organisasi, dan Informasi Asimetri Sebagai Variabel Pemoderasi. Jurnal Ekonomi dan Bisnis Islam Vol. VIII, No. 2, Juni 2014.

Uleng, N. Syamsudin. (2019). Pengaruh Sumber Daya Manusia, partisipasi anggaran, dan gaya kepemimpinan terhadap kualitas informasi laporan keuangan dan pengendalian internal sebagai variabel moderasi (studi kasus pada pemerintahan Kabupaten Takalar). Jurnal Bisnis, Manajemen dan Informatika, 16(1).

Messier, Jr, W. F. (2010). Opportunities for task-level research within the audit process. International Journal of Auditing, 14(3), 320-328.

Mokoginta, Novtania. (2017). Pengaruh Sistem Pengendalian Intern Dan Sistem Akuntansi Keuangan Daerah Terhadap Kualitas Laporan Keuangan Pemerintah. Jurnal Riset Akuntansi Going Concern 12(2), 2017.

Mulyadi. (2013). Sistem Akuntansi, Edisi Ketiga, Cetakan Keempat, Salemba Empat. Jakarta.

Natalya, Beby. (2016). Pengaruh Partisipasi Anggaran dan Akuntansi Pertanggungjawaban Terhadap Kinerja Pegawai Pada Badan Pengelola Keuangan dan Aset Daerah Kota Balikpapan. Akuntabel: Jurnal Ekonomi dan Keuangan Volume 13 (2).

Nouri, H. dan RJ Parker. (1996). "The Effect of Organizational Commitment on Relation Between Budgetary Participation and Budgetary Slack". Behavioral Research In Accounting. Vol 8. 74-90.

RA Supriyono, SU. (2000). Sistem Pengendalian Manajemen, Edisi Pertama, Yogyakarta: BPFE-Yogyakarta.

Pebrianti, SR and Nurna Aziza. (2018). Effect of Clarity of Budget Objectives, Accounting Control, Reporting Systems, Compliance with Regulation on Performance Accountability of Government Agencies. Advances in Social Science, Education and Humanities Research, volume 292.

Putra, Made Aditya. (2014). Pengaruh Partisipasi Dalam Penyusunan Anggaran Terhadap Kinerja Manajerial Pada Skpd Kabupaten Buleleng Melalui Komitmen Organisasi, Kecukupan Anggaran, Komitmen Tujuan Anggaran, Dan Job Relevant Information Sebagai Variabel Moderating. Jurnal Ilmiah Mahasiswa Akuntansi Undiksha Vol. 2 No. 1 tahun 2014.

Sawitri, Made, IGA Purnamawati, dan Nyoman T. Herawati. (2015). Pengaruh Partisipasi Penyusunan Anggaran Terhadap Kinerja Manajerial dengan Sistem Pengendalian Internal, Akuntabilitas Publik, dan Job Relevant Information sebagai Variabel 
Pemoderasi (Studi Empiris pada SKPD Kabupaten Bangli). Jurnal Ilmiah Mahasiswa Vol 3, No. 1.

Sawyer, LB, Mortimer, AD, James, HS (2003). Internal Auditing. The Practice of Internal Auditing. 5th ed. Florida: The Institute of Internal Auditor.

Siregar, Baldric. (2015). Akuntansi Sektor Publik (Akuntansi Keuangan Pemerintah Daerah Berbasis Akrual). Yogyakarta: UPP STIM YKPN.

Sumarno,. (2005). Disampaikan pada Simposium Nasional Akuntansi (SNA) VIII. Solo, 15-16 September 2005.

Tambingon. (2018). Determinant Factors Influencing the Quality of Financial Reporting Local Government in Indonesia. International Journal of Economics and Financial Issues Vol. 8(2).

Hardia Utama, M. (2015). Pengaruh Pengetahuan Dewan Tentang Anggaran Terhadap Pengawasan Keuangan Daerah Dengan Partisipasi Masyarakat Dan Transparansi Kebijakan Publik Sebagai Variabel Moderating.(Studi Empiris pada DPRD Kabupaten Boyolali) (Doctoral dissertation, Universitas Muhammadiyah Surakarta).

Yuliastuti, Yuriah, and Muhammad Agung Prabowo. (2015). "Pengaruh Partisipasi Penyusunan Anggaran Pendapatan Dan Belanja Sekolah (Apbs) Terhadap Budgetary Slack Dengan Motivasi Dan Komitmen Organisasi Sebagai Variabel Pemoderasi." Jurnal Paradigma Universitas Islam Batik Surakarta 12.02: 116376. 